\title{
I 03 I Renal dysfunction, in association with myocardial fibrosis leads to worse survival in patients with severe left ventricular dysfunction: a delayed hyperenhancement MRI study
}

\author{
Carmel M Halley*, Deborah H Kwon, Thomas P Carrigan, Randolph Setser, \\ Paul Schoenhagen, Randall L Starling, Scott D Flamm and Milind Y Desai
}

Address: Cleveland Clinic Foundation, Cleveland, OH, USA

* Corresponding author

from I th Annual SCMR Scientific Sessions

Los Angeles, CA, USA. I-3 February 2008

Published: 22 October 2008

Journal of Cardiovascular Magnetic Resonance 2008, I0(Suppl I):AI56 doi:I0.II86/I532-429X-I0-SI-AI56

This abstract is available from: http://jcmr-online.com/content/I0/SI/AI56

(c) 2008 Halley et al; licensee BioMed Central Ltd.

\section{Introduction}

Renal dysfunction in patients with severe left ventricular (LV) dysfunction is an independent risk factor for mortality. Delayed hyperenhancement magnetic resonance imaging (DHE-MRI) accurately detects myocardial fibrosis (scar), seen commonly in this group.

\section{Purpose}

We sought to determine the association of myocardial scar and renal dysfunction on survival in this group.

\section{Methods}

We studied 176 consecutive patients $(61 \pm 13$ years, $73 \%$ men) with severe LV systolic dysfunction (mean ejection fraction $(24 \pm 8 \%)$ who underwent DHE-MRI on $1.5 \mathrm{~T} \mathrm{MR}$ scanners (Siemens, Erlangen, Germany) from 2005-6. DHE-MR images were obtained in standard long and short axis orientations (covering the entire LV), after injection of Gadolinium dimenglumine using an inversion recovery spoiled gradient echo sequence: TE 4 msec, TR 8 msec, flip angle $30^{\circ}$, bandwidth $140 \mathrm{~Hz} /$ pixel, $23 \mathrm{k}$-space lines acquired every other RR-interval, field of view (varied from 228-330 in the x-direction and 260-330 in the $y$-direction) and matrix size (varied from 140-180 in the $\mathrm{x}$-direction and 256 in the $\mathrm{y}$-direction). For DHE-MRI analysis, a custom analysis package (VPT software, Siemens, Erlangen, Germany) was used to manually delineate endocardial and epicardial myocardial edges. Scar was defined as having intensity $>2$ SD above viable myocar- dium (identified by a user-specified region of interest). Glomerular filtration rate (GFR, $\mathrm{ml} / \mathrm{min} / 1.73 \mathrm{~m}^{2}$ ) was calculated using the following formula: $186 \times$ (serum creatinine $\left.{ }^{-1.154}\right) \times\left(\right.$ age $\left.^{-0.203}\right) \times 1.212$ (if black) $\times 0.742$ (if female). We divided patients into 4 groups: 1 ) GFR $>60$, no scar $(\mathrm{n}=28)$ 2) GFR $>60$ with scar $(\mathrm{n}=85) 3)$ GFR $\leq$ 60 , no scar $(\mathrm{n}=9)$ and 4$)$ GFR $\leq 60$ with scar $(\mathrm{n}=53)$.

\section{Results}

Overall, there were 24 deaths and of these, 14 patients $(65 \%)$ had myocardial scar. The incidence of deaths was highest in group 4 - there were no deaths in group 1, 7 in group 2, 3 in group 3 and 14 in group $4(p<0.001)$. Mean GFR was $70 \pm 29$ and $62(35 \%)$ patients had at-least moderate renal dysfunction $(\mathrm{GFR}<60)$. The frequency of myocardial scar was higher in patients with GFR $>60$ vs. those with GFR $\leq 60$ (92\% VS. 79\%, p = 0.02). On multiple regression (including GFR, myocardial scar, coronary artery disease, hypertension, diabetes and coronary bypass), GFR and myocardial scar were associated with mortality (both $\mathrm{p}$ value $<0.05$, overall model $\mathrm{p}$ value $<$ $0.001)$. One year survival was significantly worse for groups 2, 3 and 4, compared to group 1 ( $\log$ rank p value $<0.001)$.

\section{Conclusion}

Renal dysfunction is associated with a higher frequency of myocardial fibrosis in patients with severe LV dysfunction. Presence of renal dysfunction, myocardial fibrosis or 
both is associated with worse survival in such patients. The mechanistic association between renal dysfunction and myocardial fibrosis needs to be further defined.

Publish with Bio Med Central and every scientist can read your work free of charge

"BioMed Central will be the most significant development for disseminating the results of biomedical research in our lifetime. " Sir Paul Nurse, Cancer Research UK

Your research papers will be:

- available free of charge to the entire biomedical community

- peer reviewed and published immediately upon acceptance

- cited in PubMed and archived on PubMed Central

- yours - you keep the copyright

Submit your manuscript here:

http://www.biomedcentral.com/info/publishing_adv.asp 